\title{
Iranian EFL Learners' Achievement Goals in Relation with Their Metacognitive Reading Strategy Use
}

\author{
Mahtab Mohammadi Ghavam, Mina Rastegar, Mohammad Hasan Razmi \\ Foreign Languages Department, Shahid Bahonar University, Kerman, Iran. \\ Email: \{Nicemoon662011, Hasanrazmi2000\}@gmail.com, Rastegar@mail.uk.ac.ir \\ Received October 22 $2^{\text {nd }}, 2011$; revised November $22^{\text {nd }}, 2011$; accepted December $10^{\text {th }}, 2011$.
}

\begin{abstract}
The present study aimed at finding the relationship between the subscales of achievement goals and the frequency of metacognitive reading strategies (MRS) Iranian EFL learners use, and tried to explore any significant differences between males and females regarding achievement goals and metacognitive reading strategy use. 103 freshman and sophomore students majoring in English Literature and English Translation in Shahid Bahonar and Azad universities of Kerman took part in this study. In order to obtain the required data, two questionnaires were utilized: Achievement Goal Questionnaire (AGQ) developed by Elliot and McGregor (2001) to measure the participants' achievement goal orientations, and Metacognitive Awareness of Reading Strategies Inventory (MARSI) developed by Mokhtari and Reichard (2002) to measure the participants' frequency of metacognitive reading strategy use. The findings of this study revealed that there was a significant positive relationship between mastery-approach goal orientation and MRS use. Regarding the other three subscales of achievement goals (performance-approach, performance-avoidance, and mastery-avoidance) in relation with MRS use, all the correlations were significantly negative. Moreover, a significant difference was found between males and females regarding their achievement goals. Females were found to have higher scores of achievement goals. Regarding MRS use and gender, no significant difference was found between males and females.
\end{abstract}

Keywords: Metacognitive Reading Strategies (MRS), Achievement Goals, English as a Foreign Language (EFL)

\section{Introduction}

Reading is an essential skill and perhaps the most vital skill for second language learners to master in academic settings (Grabe, 1991). It can be considered as a gateway for getting and learning new knowledge. According to Shuyun Li and Mumby (1996), reading can be considered as a complex and demanding process in which students actively use metacognitive strategies which were defined by Oxford (1990) as the learners' behaviors for planning, arrangement, and self-assessment. Regarding the importance of reading comprehension, it can be mentioned that it is the basic goal for EFL/ESL students to gain knowledge about the world, enabling them to think about and react to what they read (Tierney, 2005). Strategic awareness and monitoring of the comprehension process are important aspects of skilled reading (Pressley \& Afflerbach, 1995; Sheorey \& Mokhtari, 2001). Although considerable research has been done on students' awareness of the metacognitive reading strategies, there has been little attention as to how the context of learning and students' motivation affects the actual use of these strategies. One important aspect of motivation is the achievement goal orientation which can be described as the integrated patterns of beliefs helping the learners approach, engage in and respond to achievement related situations (Ames, 1992; Elliot \& McGregor, 2001; Meece, Blumenfeld, \& Hoyle, 1998). The relationship among achievement goals, learning strategies and academic achievement has been widely investigated (e.g. Chan, Lau, Leung, \& Moore, 2005; Elliot, McGregor \& Gable, 1999; Pintrich \& Schunk, 2000), but the study examining the relationship between learners' achievement goals and metacognitive reading strategy use has been lacking. This study, therefore, aimed at investigating Iranian EFL learners' achievement goals in relation with their use of metacognitive reading strategies. Furthermore, the differences between males and females re- garding their achievement goals and metacognitive reading strategy use, was another issue to be explored in this study.

\section{Metacognitive Reading Strategies}

Metacognition was first introduced in the 1970s by Flavell, and has widely attracted attention in the educational domain (Baker, 2005; Samuels, Ediger, Willcut, \& Palumbo, 2005). Flavell (1979) defined metacognition as the "knowledge and cognition about cognitive phenomena" (p. 906). Baker and Brown (1984) divide metacognition into two categories: knowledge about cognition which is one's awareness and appraisal of one's own cognitive process, and regulation of cognitive knowledge which can be defined as strategies leading to the achievement of self-regulation. After this study, Flavell (1987) divided metacognition into three categories: including knowledge of person variables, task variables, and strategy variables. Strategy is conceived as a deliberate goal-directed action (Pereira-Laird \& Deane, 1997), which can be either conscious or unconscious or automatic. Therefore, there was a move from metacognitive knowledge to metacognitive strategies. Oxford (1990) defined metacognitive strategies as learners' behaviors for planning, arrangement, and self-assessment including directed practice, opportunities, and so forth.

Reading strategies have been conceptualized as specific, deliberate, goal-oriented mental processes or behaviors controlling and modifying the reader's efforts to decode, understand the words, and construct the text's meaning (Garner, 1987; Afflerbach, Pearson, \& Paris, 2008). Reading strategies have been categorized as cognitive, metacognitive and social affective strategies (Chamot, 1987; O’Malley \& Chamot, 1990). Learners' metacognitive strategic knowledge in reading is composed of thinking about the reading process, planning for reading, monitoring comprehension during the reading process, evaluating the effectiveness of strategies used in reading, and 
verifying what is read as well as specific steps in problem solving during comprehension (Flavell, 1987; O'Malley \& Chamot, 1990; Wenden, 1991).

\section{Achievement Goal Orientations}

Although academic discussions of human motivation developed in the last century, research in this area has grown in the last two decades with the study of achievement goal orientation (Dweck, 1986; Nicholls, 1984). Achievement goals are relatively stable orientations that the learners bring to the learning situations (Lehmann, 2002). They are composed of reasons and purposes that students consider for achievement tasks (Gutman, 2006; Sins, Vanjoohngen, Saveisbergn, \& Hout-Wolters, 2008; Bipp, Steinmayr, \& Spinath, 2008).

Initial theoretical and empirical research on achievement goals followed a dichotomous framework grounded in the distinction between mastery and performance (Dweck, 1986; Nicholls, 1984). Mastery goals focus on the development of competence, and performance goals focus on the demonstration of competence. This initial distinction of mastery versus performance developed from studies demonstrating that more adaptive results are associated with mastery goals while less adaptive results are related to performance goals (Ames, 1992; Pintrich \& Schunk, 1996). According to Ames (1992), while mastery goal oriented learners tend to improve their ability, understanding, and level of competence or to gain a sense of mastery based on self- referenced criteria, performance goal oriented learners tend to focus on and determine their ability by outperforming others in competitions, achievements or grades, and receive public recognition for their superior performance.

More recent theoretical and empirical research has followed a trichotomous model grounded in the mastery-performance distinction and the difference between approach and avoidance motivation (Elliot \& Church, 1997). In performance approach orientation, the learner strives to demonstrate high ability, but in performance avoidance orientation, the learner intends to avoid demonstrating low ability (Elliot, 1999) Therefore, the trichotomous model includes mastery goal, performance approach, and performance avoidance orientations.

Elliot and McGregor (2001) further developed the trichotomous model into a four factor framework by applying the approach-avoidance distinction to the mastery goal orientation. Therefore, the four factor framework consists of mastery approach, mastery avoidance, performance approach, and performance avoidance goals. Recently, a fifth type of motivation, named work avoidance, has been added to the four factor framework which seems to be of interest in the educational setting (Harackiewicz, Barron, Carter, Lehto, \& Elliot, 1997; Pieper, 2003).

\section{Literature Review}

Deyreh and Banijamali (2009) carried out a research to study the effect and contribution of motivational factors (self-efficacy, mastery goals, and instrumentality) on cognitive and metacognitive strategies used in learning processes. They found that cognitive and metacognitive strategies were influenced by perceived instrumentality, mastery goals, and self-efficacy.

Kharazi, Ezhehei, Ghazi Tabatabaei, and Kareshki (2008) carried out a research to study the relationships between achievement goals, self-efficacy and metacognitive strategies in Tehran high schools, based on a causal model. They selected a sample of 685 third grade high school students. They found mutual significant correlations between achievement goals, self-efficacy and metacognitive strategies components.

Mohsenpour, Hejazi, and Kiamanesh (2008) carried out a study to investigate the effect of self-efficacy and achievement goals as motivational variables and learning strategies and persistence as cognitive variables on students' mathematics achievement. The results revealed that there were direct effects of performance-approach goals, avoidance-approach goals, selfefficacy, learning strategies and persistence on mathematics achievement.

Pintrich and DeGroot (1990), and Pintrich and Garcia (1991) found that the learners who select mastery goal orientations show higher levels of cognitive and metacognitive strategies than those who focus on proving their abilities to others or avoiding the perception of incompetence. Moreover, a moderate to strong positive relationship was found between learners' use of metacognitive strategies and their academic achievement.

\section{Research Questions}

This study aimed at finding the answers to the following research questions:

1) Are there any significant relationships between achievement goals and the frequency of metacognitive reading strategies Iranian EFL learners use?

2) Are there any significant differences between males and females regarding their achievement goals, and metacognitive reading strategy use?

\section{Methodology}

\section{Participants}

The participants of this study were 103 male and female freshman and sophomore EFL students majoring in English Literature or English Translation at Shahid Bahonar and Azad Universities of Kerman. These participants were randomly chosen.

The rationale behind selecting freshman and sophomore students was due to this study's aim at identifying the EFL learners' metacognitive strategies in reading and finding the relationship between students' achievement goal orientations and their metacognitive reading strategy use.

\section{Instruments}

In this study, the following instruments were used to collect the required data:

1) Achievement Goal Questionnaire (AGQ) developed by Elliot and McGregor (2001).

2) Metacognitive Awareness of Reading Strategies Inventory (MARSI) developed by Mokhtari and Reichard (2002).

In order to measure the students' achievement goals in the classroom context, Elliot and McGregor's (2001) 12-item AGQ was used. This questionnaire allows responses ranging from 1 (not at all true of me) to 7 (very true of me) and represent four possible goal orientations: namely, mastery-approach, masteryavoidance, performance-approach, and performance-avoidance. According to Wang, Liu, and Chye (2010), the internal consistency coefficients of the mastery-approach $(\alpha=.79)$, performance-approach $(\alpha=.88)$, mastery-avoidance $(\alpha=.79)$, and performance-avoidance goal orientation $(\alpha=.73)$ were satisfactory. 
Metacognitive Awareness of Reading Strategies Inventory (MARSI), designed by Mokhtari and Reichard (2002), was designed to measure adolescent and adult students' awareness and use of reading strategies while reading academic or schoolrelated materials. The MARSI Questionnaire, which allows responses from 1 (I never or almost never do this) to 5 (I always or almost always do this), measures three broad categories of reading strategies including: Global reading strategies (GLOB), Problem-solving strategies (PROB), and Support reading strategies (SUP). The 30-item questionnaire was validated by Mokhtari and Reichard (2002) and the internal consistency reliability coefficient for its three above subscales ranged from .89 to .93 and reliability for the total sample was .93 , showing a reasonably dependable measure of metacognitive awareness of reading strategies.

\section{The Pilot Study of the Instruments}

Before launching the main study, AGQ and MARSI were piloted with 30 freshman and sophomore EFL students who were randomly selected at Shahid Bahonar and Azad universities of Kerman. Cronbach alpha showed that the reliability of AGQ of the pilot study was .80. The reliability of the AGQ in the main study among 103 participants came out to be .82 . Moreover, the reliability of MARSI of the pilot study was .79. The reliability of the MARSI in the main study came out to be 84 .

\section{Data Collection Procedures}

AGQ and MARSI scales were distributed among the participants simultaneously. Participants were given time (15 - 20 mins) to answer these questionnaires and there were accompanying instructions. They were assured that the information would be kept completely confidential. They were also told that the gathered information would be used only for research purposes.

\section{Results}

The descriptive statistics of the variables of the study, namely achievement goals and metacognitive reading strategy use as well as the achievement goal subscales have been presented in Tables 1 and 2 .

\section{Achievement Goals Subscales in Relation with MRS Use}

In order to answer the first research question regarding the relationship between the subscales of achievement goals and MRS use, four Pearson Product-Moment Correlation Coefficients were conducted (Table 3 ).

Regarding the first subscale of achievement goals, that is mastery-approach, and MRS use, a significant positive relationship was found $(\mathrm{r}=.85)$. Concerning the second subscale, that is mastery-avoidance, and MRS use, a significant negative relationship was found $(\mathrm{r}=-.78)$. According to Table 3, regarding the third subscale of achievement goals, namely, performance-approach and MRS use, a significant negative relationship was found $(r=-.81)$. Finally, concerning the last subscale, performance-avoidance and MRS use, a significant relationship was found $(\mathrm{r}=-.83)$.

\section{Gender Differences and Achievement Goals}

In order to investigate the second question regarding the gender differences and Learners' achievement goals, an Independ-

Table 1.

The descriptive statistics of the variables.

\begin{tabular}{ccccccccc}
\hline & N & Range & Min & Max & Mean & SD & Variance \\
\hline MRS & 103 & 78 & 45 & 123 & 91.46 & 24.55 & 602.93 \\
Achievement Goals & 103 & 66 & 16 & 82 & 53.60 & 22.89 & 523.98 \\
\hline
\end{tabular}

Table 2.

The descriptive statistics of the subscales of achievement goals.

\begin{tabular}{ccccccc}
\hline & Range & Min & Max & Mean & SD & Variance \\
\hline Mastery-approach & 18 & 3 & 21 & 13.65 & 5.81 & 33.83 \\
Mastery-avoidance & 18 & 3 & 21 & 10.66 & 5.99 & 35.97 \\
Performance-approach & 18 & 3 & 21 & 10.63 & 6.00 & 36.03 \\
Performance-avoidance & 18 & 3 & 21 & 10.75 & 6.05 & 36.61 \\
\hline
\end{tabular}

Table 3.

Correlations of the subscales of achievement goals and MRS use.

\begin{tabular}{ccccc}
\hline & Mastery-approach & Mastery-avoidance & performance-approach & Performance-avoidance \\
\hline MRS Use & & & & $-.83^{* *}$ \\
Pearson Correlation & $.85^{* *}$ & $-.78^{* *}$ &. $.81^{* *}$ & .000 \\
Sig. (2-tailed) & .000 & .000 & .000 & 103 \\
$\mathrm{~N}$ & 103 & 103 & 103 & 103 \\
\hline
\end{tabular}

**Correlation is significant at the .01 level (2-tailed). 
ent T-test was run. According to the results, since $\mathrm{P}=.000$ is less than $\alpha=.05$, there is a significant difference among males and females regarding their achievement goals (Table 4). Comparing the means obtained from male and female participants, it can be concluded that females' total achievement goal is more than those of males.

\section{Gender Differences and MRS Use}

In order to investigate the gender differences and MRS use, an Independent T-test was run. According to the results, since $\mathrm{P}$ $=.231$ is more than $\alpha=.05$, there is not any significant difference among males and females regarding their MRS use (Table 5).

\section{Discussion}

Concerning the first research question of this study, that is the relationship between the subscales of achievement goals and the learners' metacognitive reading strategy use, some significant relationships were found that are discussed one by one.

According to the results of this study, there is a significant positive relationship between mastery-approach goals and metacognitive reading strategy use. This finding is in line with that of Ames and Archer (1988), Nolen and Haladyna (1990), Schmidt and Ford (2003). Other researchers have found that students with mastery goals devote more effort to monitoring their learning; seek evaluative feedback (Butler, 1993; VandeWalle Brown, Cron, \& Slocum, 1999) and persist longer when faced with negative feedback (VandeWalle et al., 1999).

Regarding the relationship between performance-approach goals and metacognitive reading strategy use, a significant negative relationship was found in this study. According to Schmidt and Ford (2003), while research shows that performance-avoidance goals are negatively related to metacognition, the relationship between performance-approach goals and metacognition is vague. Some studies have found a weak positive relationship between metacognition and performance-approach goals (Ames \& Archer, 1988; Archer, 1994; Meece et al., 1988; Nolen \& Haladyna, 1990), whereas other studies cite a negative relationship (Wolters, 1998) or no relationship (Ford, Smith, Weissbein, Gully, \& Salas, 1998).

According to this study's results, mastery-avoidance and performance-avoidance goals are negatively related to learners' frequency of metacognitive reading strategy use. It can be inferred that students who avoid demonstrations of incompetence are less likely to use metacognitive strategies that foster a deep understanding of material. In addition, avoidance goals are found to be related to negative results including test anxiety, poor academic performance, and fear of failure (Elliot, 1999; Elliot \& Church, 1997).

Regarding the second question of this study, that is the analysis of gender differences in learners' achievement goals and metacognitive reading strategy use, it was found that there is a significant difference between males and females regarding their achievement goals. Comparing the obtained means from male and female participants, it was concluded that females' total achievement goal is more than males'. This finding is in line with Kenny-Benson et al. (2006), Eccles, Wigfield, Harold, and Blumenfeld (1993), who found that boys and girls take different approaches to how they handle and view their academic tasks, which may relate to the type of goal orientations that they also employ. Concerning the analysis of gender differences in learners' metacognitive reading strategy use, no significant difference was found among males and females. This finding is in line with that of Zare-ee (2007), Cooper (2004), but is in contrast with that of Sy (1994), Bacon (1992), Oxford (1989), Ehrman and Oxford (1989).

Due to limitations of research, this study was carried out in two educational contexts, with a limited number of freshman and sophomore EFL students. It would be useful to replicate and extend the recent research to larger samples with different proficiency levels in other educational contexts such as ESL settings. Furthermore, this study relies on gathering data by means of two self-report questionnaires. It is possible for future researchers to utilize other means of data collection such as interviews and observations along with using self-report questionnaires. As mentioned before, metacognitive reading strategies can be in relation with a number of factors dealing with motivation and context of learning. This study, due to time and space limitations, only explored one aspect of motivation, namely achievement goal orientations in relation with the learners' choices of metacognitive reading strategies. Investigating other factors in learning context can be the focus of future studies.

\section{Conclusion}

Strategic awareness and monitoring of the comprehension process are important aspects of skilled reading (Pressley \& Afflerbach, 1995; Sheorey \& Mokhtari, 2001). This study, therefore, tried to find the ways in which factors like motivation

Table 4.

Independent T-test for achievement goals and gender.

\begin{tabular}{ccccccc}
\hline Groups & $\mathrm{N}$ & Mean & $\mathrm{SD}$ & $\mathrm{t}$ & $\mathrm{df}$ & $\mathrm{P}$ \\
\hline Male & 38 & 37.23 & 20.65 & -6.6 & 101 & .000 \\
Female & 65 & 63.16 & 18.34 & & & \\
\hline
\end{tabular}

Table 5.

Independent T-test for MRS use and gender.

\begin{tabular}{ccccccc}
\hline Groups & $\mathrm{N}$ & Mean & SD & $\mathrm{t}$ & $\mathrm{df}$ & $\mathrm{P}$ \\
\hline Male & 38 & 87.65 & 25.09 & -1.2 & 101 & .231 \\
Female & 65 & 93.69 & 24.14 & & & \\
\hline
\end{tabular}


and specifically achievement goals affect the metacognitive strategy use in a reading comprehension class. Achievement goal was regarded as a four-factor construct including masteryapproach, mastery-avoidance, performance-approach, and performance-avoidance goals. Therefore, this study, found a significant positive relationship between mastery-approach goal and metacognitive reading strategy use. With regard to performance-approach, performance-avoidance, and mastery-avoidance goals, a significant negative relationship was found.

The implications of these findings are that in educational contexts a great deal of attention should be paid to constructs such as motivation, achievement goals, and metacognition. By the same token, in language learning classes, attention to the aforementioned constructs can help the learners boost their learning abilities in different language skills. To achieve such a goal, English teachers should be trained to get familiar with these constructs; moreover, they should try to raise the students' awareness about the constructs. In this way, the students can improve their reading comprehension. Therefore, it can be concluded that to enhance the language learners' metacognitive strategy use in reading, teachers should firstly try to investigate the dominant achievement goals in their students, and secondly try to encourage mastery-approach goals in their students which leads to improving their ability and understanding, their level of competence or gaining a sense of mastery based on self-referenced criteria (Ames, 1992). Students that do not use strategies should not be left alone. They might have learnt the strategies but they are not able to use them practically. They may not lag behind in strategy learning but in other factors related to the strategy use, such as achievement goals. In a broader scope and in light of the findings of the present study, material designers, curriculum developers, and syllabus designers in the area of applied linguistics can take such implications into consideration. The findings of this study might also encourage the other researchers to investigate the influence of other factors in learning context on learners' metacognitive reading strategy use, or find the relationship between achievement goals and metacognitive strategies in areas of listening or writing in other academic contexts.

\section{Acknowledgements}

We would like to acknowledge Mr. Mehrdad Nazarieh's cooperative effort. He steered us through troubled waters when we were incapable of paying the application fee.

\section{References}

Afflerbach, P., Pearson, P. D., \& Paris, S. G. (2008). Clarifying differences between reading skills and reading strategies. The Reading Teacher, 61, 364-373. doi:10.1598/RT.61.5.1

Ames, C. (1992). Classrooms: Goals, structures, and student motivation. Journal of Educational Psychology, 84, 261-271.

doi:10.1037/0022-0663.84.3.261

Ames, C., \& Archer, J. (1988). Achievement goals in the classroom: Goals, structures, and student motivation. Journal of Educational Psychology, 80, 260-267. doi:10.1037/0022-0663.80.3.260

Archer, S. L. (1994). Interventions for adolescent identity development. Thousand Oaks: Sage.

Bacon, S. M. (1992). Phases of listening to authentic input in Spanish: A descriptive study. Foreign Language Annals, 25, 317-333. doi:10.1111/j.1944-9720.1992.tb00552.x

Baker, L. (2005). Developmental differences in Metacognition: Impli- cations for metacognitively oriented reading instruction. In S. E. Israel, K. L. Bauserman, C. C. Block and K. Kinnucan-Welsch (Eds.), Metacognition in Literacy Learning: Theory, Assessment, Instruction and Professional Development (pp. 61-79). Abingdon: Lawrence Erlbaum Associates.

Baker, L., \& Brown, A. L. (1984). Metacognitive skills and reading. In P. D. Pearson, R. Barr, M. L. Kamil and P. Mosenthal (Eds.), Handbook of Reading Research (pp. 353-394). New York: Longman.

Bipp, T., Steinmayr, R., \& Spinath, B. (2008). Personality and achievement motivation: Relationship among big five domain and facet scales, achievement goals and intelligence. Personality and Individual Differences, 44, 1454-1464. doi:10.1016/j.paid.2008.01.001

Butler, R. (1993). Effects of task-and ego-achievement goals on information seeking during task engagement. Journal of Personality and Social Psychology, 65, 18-31. doi:10.1037/0022-3514.65.1.18

Chamot, A., \& O’Malley, M. (1987). The cognitive academic language learning approach: A bridge to the mainstream. TESOL Quarterly, 21, 227-249. doi: $10.2307 / 3586733$

Chan, K. W., Lau, P. Y., Leung, M. T., \& Moore, P. J. (2005). Students' goal orientations, study strategies and achievement: A closer look in Hong Kong Chinese cultural context. The Asia-Pacific Education Researcher, 14, 1-26.

Cooper, S. S. (2004). Metacognition in the adult learner. URL (last checked 23 March 2010)

http://www.lifecircles-inc.com/metacognition.htm

Deyreh, E., \& Banijamali, S. H. (2009). The study of contribution of motivational factors on cognitive and metacognitive strategies used in learning process. Psychological Studies, 5, 47-62.

Dweck, C. S. (1986). Motivational processes affecting learning. American Psychologist, 41, 1040-1048.

doi:10.1037/0003-066X.41.10.1040

Eccles, J. S., Wigfield, A., Harold, R. D., \& Blumenfeld, P. (1993). Age and gender differences in children's self- and task perceptions during elementary school. Child Development, 64, 830-847. doi: $10.2307 / 1131221$

Ehrman, M. E., \& Oxford, R. L. (1989). Effects of sex differences, career choice, and psychological type on adult language learning strategies. Modern Language Journal, 73, 1-13. doi:10.1111/j.1540-4781.1989.tb05302.x

Elliot, A. J. (1999). Approach and avoidance motivation and achievement goals. Educational Psychologist, 34, 169-189. doi:10.1207/s15326985ep3403 3

Elliot, A. J., \& Church, M. A. (1997). A hierarchical model of approach and avoidance achievement motivation. Journal of Personality and Social Psychology, 72, 218-232. doi:10.1037/0022-3514.72.1.218

Elliot, A. J., \& McGregor, H. A. (2001). A $2 \times 2$ achievement goal framework. Journal of Personality and Social Psychology, 80, 501519. doi:10.1037/0022-3514.80.3.501

Elliot, A. J., McGregor, H. A., \& Gable, S. L. (1999). Achievement goals, study strategies, and exam performance: A mediational analysis. Journal of Educational Psychology, 91, 549-563. doi:10.1037/0022-0663.91.3.549

Flavell, J. H. (1979). Metacognition and cognitive monitoring: A new area of cognitive developmental inquiry. American Psychologist, 34, 906-911. doi:10.1037/0003-066X.34.10.906

Flavell, J. H. (1987). Speculation about the nature and development of metacognition. In: F. E. Wernert and R. H. Kluwe (Eds.), Metacognition, Motivation and Understanding. Hillsdale, NJ: Lawrence Erlbaum Associates.

Ford, J. K., Smith, E. M., Weissbein, D. A., Gully, S. M., \& Salas, E. (1998). Relationships of goal orientation, meta-cognitive activity, and practice strategies with learning outcomes and transfer. Journal of Applied Psychology, 83, 218-233. doi:10.1037/0021-9010.83.2.218

Garner, R. (1987). Metacognition and reading comprehension. Norwood, NJ: Ablex.

Grabe, W. (1991). Current developments in second language reading research. TESOL Quarterly, 25, 375-406. doi:10.2307/3586977

Gutman, L. M. (2006). How student and parent goal orientation and classroom goal structures influence the math achievement of African Americans during high school transition? Contemporary Educational 
Psychology, 31, 44-63. doi:10.1016/j.cedpsych.2005.01.004

Harackiewicz, J. M., Barron, K. E., Carter, S. M., Lehto, A. T., \& Elliot, A. J. (1997). Predictors and consequences of achievement goals in the college classroom: Maintaining interest and making the grade. Journal of Personality and Social Psychology, 73, 1284-1295. doi:10.1037/0022-3514.73.6.1284

Kenny-Benson, G. A., Pomerantz, E. M., Ryan, A. M., \& Patrick, I-I. (2006). Sex differences in math performance: The role of children's approach to schoolwork. Developmental Psychology, 42, 1 1-26.

Kharazi, S. A. N., Ezhehei, J., Ghazi Tabatabaei, M., \& Kareshki, H. (2008). An investigation of the relationships between achievement goals, self-efficacy and metacognitive strategies: Testing a causal model. Journal of Psychology and Education, 38, 69-87.

Lenmann, R. L. (2002). Enhancing the valuing of commitment to effortful achievement: An achievement goal approach. Proceeding of the AERA Annual Meeting, University of Minnesota, 1-19.

Meece, J. L., Blumenfeld, P. C., \& Hoyle, R. H. (1988). Students' goal orientations and cognitive engagement in classroom activities. Journal of Educational Psychology, 80, 514-523. doi:10.1037/0022-0663.80.4.514

Mohsenpour, M., Hejazi, E., \& Kiamanesh, A. R. (2008). The roal of self-efficacy, achievement goals, learning strategies and persistence in math achievement of 11th grade high school students in Tehran. Journal of Educational Innovations, 24, 153-172.

Mokhtari, K., Reichard, C. (2002). Assessing students' metacognitive awareness of reading strategies. Journal of Educational Psychology, 94, 249-259. doi:10.1037/0022-0663.94.2.249

Nicholls, J. G. (1984). Achievement motivation: Conceptions of ability, subjective experience, task choice, and performance. Psychological Review, 91, 328-346. doi:10.1037/0033-295X.91.3.328

Nolen, S. B., \& Haladyna, T. M. (1990). Motivation and studying in high school science. Journal of Research in Science and Teaching, 27, 115-126. doi:10.1002/tea.3660270204

O'Malley, J. M., \& Chamot, A. U. (1990). Learning strategies in second language acquisition. Cambridge, UK: Cambridge University Press.

Oxford, R. L. (1990). Language learning strategies: What every teacher should know. New York: Newbury House.

Oxford, R. L. (1989). Use of language learning strategies: A synthesis of studies with implications for strategy training. System, 17, 235247. doi:10.1016/0346-251X(89)90036-5

Pereira-Laird, J. A., \& Deane, F. P. (1997). Development and validation of a self-report measure of reading strategy use. Reading Psychology: An International Journal, 18, 185-235.

Pieper, S. (2003). Refining and extending the $2 \times 2$ achievement goal framework: Another look at work-avoidance. Dissertation Abstracts International, 64, 4436.

Pintrich, P. R., \& DeGroot, E. V. (1990). Motivational and self-regulated learning components of classroom academic performance. Journal of Educational Psychology, 82, 33-40. doi:10.1037/0022-0663.82.1.33

Pintrich, P. R., \& Garcia, T. (1991). Student goal orientation and self-regulation in the college classroom. In M. L. Maehr and P. R. Pintrich (Eds.), Advances in Motivation and Achievement (pp. 371-
402). Greenwich, CT: JAI Press.

Pintrich, P. R., \& Schunk, D. H. (2000). Motivation in education. Theory, research, and applications (2nd ed.). Englewood Cliffs, NJ: Prentice Hall.

Pintrich, P. R., \& Schunk, D. H. (1996). Motivation in education: Theory, research, and applications. Englewood Cliffs, NJ: Prentice Hall.

Pressley, M., \& Afflerbach, P. (1995). Verbal protocols of reading: The nature of constructively responsive reading. Hillsdale, NJ: Lawrence Erlbaum.

Samuels, S. J., Ediger, K.-A. M., Willcutt, J. R., \& Palumbo, T. (2005). Role of automaticity in metacognition and literacy instruction. In $\mathrm{S}$. E. Israel, K. L. Bauserman, C. C. Block and K. Kinnucan-Welsch (Eds.), Metacognition in Literacy Learning: Theory, Assessment, Instruction and Professional Development (pp. 42-59). Abingdon: Lawrence Erlbaum Associates.

Schmidt, A. M., \& Ford, K. J. (2003). Learning with a learner control-training environment: The interactive effects of goals orientation and metacognitive instruction on learning outcomes. Personnel Psychology, 56, 380-405. doi:10.1111/j.1744-6570.2003.tb00156.x

Sheorey, R., Mokhtari, K. (2001). Coping with academic materials: Differences in the reading strategies of native and non-native readers System, 29, 431-449. doi:10.1016/S0346-251X(01)00039-2

Shuyun, L., \& Munby, H. (1996). Metacognitive strategies in second language academic reading: A qualitative Investigation, English for specific purposes, The American University Great Britain, 15, 199 216.

Sins, P. H. M., Vanjoohngen, W. R., Saveisbergn, E. R., \& HoutWolters, B. V. (2008). Motivation and performance within a collaborative computer-based modeling task: Relations between students' achievement goal orientations, self-efficacy, cognitive processing and achievement. Contemporary Educational Psychology, 33, 58-77. doi:10.1016/j.cedpsych.2006.12.004

Sy, B. M. (1994). Sex differences and language learning strategies. Paper presented at the 11th Conference of Teachers of English to Speakers of Other Languages of the Republic of China, Taiwan.

Tierney, J. E. (2005). Reading strategies and practices (6th ed.). Boston, MA: Pearson Education, Inc.

VandeWalle D., Brown, S. P., Cron, W. L., \& Slocum, J. W. (1999). The influence of goal orientation and self-regulation tactics on sales performance: A longitudinal field test. Journal of Applied Psychology, 84, 249-259. doi:10.1037/0021-9010.84.2.249

Wang, C. K., Liu, W. S., \& Chye, S. (2010). Achievement goals, implicit theories and behavioral regulation among polytechnic engineering students. The International Journal of Research and Review, 5, 1-17.

Wenden, A. L., (1991). Learner strategies for learner autonomy: Planning and implementing learner training for language learners. Hertfordshire, UK: Prentice-Hall International.

Wolters, C. A. (1998). Self-regulated learning and collage students' regulation of motivation. Journal of Educational Psychology, 90, 224-235. doi:10.1037/0022-0663.90.2.224

Zare-ee, A. (2007). The relationship between cognitive and meta-cognitive strategy use and EFL reading achievement. Journal of Applied Psychology, 2, 105-119. 